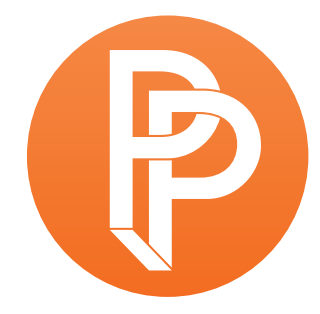

PERFORMANCE

PHILOSOPHY

\title{
TO REPEAT OR NOT TO REPEAT: THAT IS THE QUESTION
}

\section{LEO CABRANES-GRANT UNIVERSITY OF CALIFORNIA-SANTA BARBARA}

I had never been in Copenhagen before, yet this was my second visit to the city. The purpose of my travel was to inhabit, at least for several days, the urban environment that once contained the peripatetic musings of Søren Kierkegaard. I went to Denmark's capital in order to get closer to a vanished writer, a person now gone and replaced by his textual remnants. Words incite motions: I was there, standing right in front of the Vor Frue Kirke, in response to certain pages once read and pondered. My trip was a tribute to the affective consequences of libraries-books can become maps, passions, curiosities, displacements, attractions, resistances, temporalities. Ink inflects life. In addition, after being in Europe I was planning on spending the upcoming summer back in the United States, learning the Danish language at the Kierkegaard Center in St. Olaf College, Minnesota. I'd reached the point where translation was no longer enough-I demanded a direct acquaintance with the original sound of Kierkegaard's multiple voices. After many years of conversations and reasonings and debates, our friendship had turned into a relationship.

I knew Copenhagen-I had made a list of the locations I wanted to see again. The Vor Frue Kirke (the Church of Our Lady) was a fundamental piece in my exploration. Kierkegaard lived just across the street during the last years of his life; he attended services and preached there; his controversial funeral started in front of its symmetrical pews. The classical lines of the building and the white walls inside are set off balance by the gestures of Thorvaldsen's enormous statues of the Apostles. Christ's athletic effigy opens his arms at the altar while a kneeling angel welcomes us. Somehow it all works to create a sense of controlled devotion. A deliberate effort has been made to impress without falling into saturation. I entered the church and felt a sense of recognition and familiarity. The reality was that I had been there before arriving - I had developed a detailed 
understanding of the conditions of the place in advance of my somatic confrontation with the architecture.

To what extent does imagination qualify presence? Was I experiencing a repetition or a reminiscence? This is a common experience for all scholars-we are very much aware of what we want to find by the time we face some of our objects of inquiry and desire. Knowledge seems to include, quite frequently, this affective power to pre-envision things. Often enough, the personal encounter has to compete with our hindsight, to measure up (or down) to the forethoughts of our methodology. Before coming to Copenhagen, my position had been proleptic; once I was there, a retroactive review of my expectations had become necessary. My present was caught within two forms of recollection-I was remembering the Vor Frue Kirke forwards and backwards simultaneously.

Actuality - the here and now of perception and thought-is always Janus-like. Few thinkers have been so invested in grasping this conundrum as Kierkegaard was; for him, the tension between remembrance and immediacy was central to the life of the self. He was able to explore this issue right after breaking his engagement to Regine Olsen, when he decided to leave Copenhagen in order to attend Schelling's lectures in Berlin. It was Schelling's emphasis on actuality that attracted him to the lectures. But Kierkegaard tired of Schelling very quickly; surrounded by a foreign language, he felt compelled to immerse himself in his own, and he wrote at full speed some of his first important works (such as Either/Or). He also wrote many letters to his relatives and his friend Emil Boesen, trying to monitor the effects his abrupt absence from Copenhagen was having over public opinion and the behavior of his ex-fiancée. Through these letters we can see Kierkegaard slowly discovering the power of distance over presence: by not being in Copenhagen physically, he had managed to intensify the affective impact of his emotional choices both on himself and on others. Although he was going to return to Berlin in the future, the transformative consequences of this first visit would never happen again.

This discovery lies at the center of one of Kierkegaard's most intriguing books, Repetition, published in 1843. ${ }^{1}$ In Danish, the title of the book-Gjentagelsen-has connotations that are too easily overlooked in the English version. Tage implies an action-taking something from a shelf, or taking a serious attitude, or taking a city. G(j)en is associated with igen, which means getting something back (as when a friend returns a book to us, or when something is recovered). Gjentagelsen is not only about iteration, but about re-possession: the question is not merely wether we can do something once more, but also wether we can take the same object back again. This explains why Kierkegaard defines his book as an "Essay in Experimental Psychology" ("Et Forsøg i den experimenterende Psychologi"). Forsøg-the word translated by Piety as "essay" and by the Hongs as "venture"-implies experimentation from the start (a trial) or an "imaginary construction", according to the Hongs (Kierkegaard 2000, xxx); today a forsøgsdyr is a test animal (like a guineapig). 
So the text presents itself as an attempt to make a psychological case-study. ${ }^{2}$ But what exactly is the book analyzing? ${ }^{3}$ When Constantine Constantius (Kierkegaard's alter-author) talks about being able (or not) to take back Berlin, he is referring both to the location and to a particular mood once tied to it. (The alter-author's name, of course, is already playing a trick on us with its echoic construction). During my visit to Copenhagen, my challenge was to see if I could take back my researched city while I was also taking in the material city in front of me. In my case, my Copenhagen story became a tale of two cities: one studied in advance before, one walked about then-and both cities existing for me now as anamnesis, a recalling. In Gjentagelsen Constantin Constantius discovers that this Berlin will never be that Berlin again-a repetition of place never leads to a repetition in time. Psychologically-no matter how many times we go back to Berlin or Copenhagen - we will always be visiting a different city.

It is important to clarify at this point some of the consequences of this argument. Constantin is going to suggest that accepting these complications is the key to an endurable life. The measure of a person's wisdom is the way one deliberately re-engages the facts of everyday existence while still knowing that they are both foreseeable and irreplaceable:

\begin{abstract}
[O]nly a person who does not delude himself that repetition ought to be something new, for then he tires of it, is genuinely happy. It requires youthfulness to hope and youthfulness to recollect, but it requires courage to will repetition. He who only hope is cowardly. He who wants only to recollect is a voluptuary. But he who wills repetition, he is a man, and the more emphatically he has endeavoured to understand what this means, the deeper he is a human being. But he who does not grasp that life is repetition and that this is the beauty of life, has condemned himself and deserves nothing better that what will happen to him-death. (Piety translation, 4)
\end{abstract}

Life is thus a persistent "déja vu all over again" situation (as baseball player Yogi Berra would have called it). Constantius claims that repetition should be seen primarily as a transitional juncture, an effect of motion:

\footnotetext{
The dialectic of repetition is easy, because that which is repeated has been, otherwise it could not be repeated; but precisely this, that it has been, makes repetition something new [...] When one says that life is repetition, one also says that that which has existed now comes to be again. When one lacks the categories of recollection and repetition, all life is dissolved into an empty, meaningless noise. (Piety translation, 19)
}

Without a sense of orientation-a way to mark past, present, and future-we would be unable to narrate our life. But we know those temporal distinctions because we can compare is, was, and will be through a double operation that re-cognizes similarities while also acknowledging a failure to fully re-enact the former circumstances of an event. Embracing this paradox is, for Constantius, a sign of spiritual intelligence and strength: 
He who chooses repetition, he lives [...] What would life be without repetition? Who would want to be a tablet on which life wrote something new every moment, or a memorial to something past? [...] If God Himself had not willed repetition, there would have never been a world. [...] The world consists of repetition. Repetition is actuality and the earnestness of existence. (Piety translation, 4)

Without repetition life would be almost illegible (something radically new is not easily re-cognized or apprehended) or something purely commemorative (a constant reference to previous instantiations). Repetition is actuality-the being there of life itself. Among his predecessors, Kierkegaard's understanding of repetition is maybe closer to Heraclitus (that same river, never again) than to Aristotle (repetition as imitation) or Hume (repetition as a process that conflates habit with causality). And Kierkegaard quite explicitly rejects Hegel's dialectical cycles (the detailed unfolding of reality-as-thought via the concept). Kierkegaard claims that his concept of repetition is much more accurate than "mediation", that indispensable step into the Hegelian system. If mediation is, after all, a specific type of repetition, Hegel has been paying too much attention to the wrong idea:

\begin{abstract}
[R]epetition is a decisive expression for what 'recollection' was for the Greeks. Just as they taught that all knowledge is recollection, thus will modern philosophy teach that life itself is repetition [...] Repetition and recollection are the same movement, just in opposite directions, because what is recollected has already been and is thus repeated backwards, whereas genuine repetition is recollected forwards. (Piety translation, 3)
\end{abstract}

While looking backwards can be a source of sorrow, looking forward is an expression of commitment to life itself-a desire to move on into what life is.

Constantius decides to visit Berlin again in order to test this assertion. But nothing goes as planned: his apartment, his landlord and the streets fail to bring back former perceptions and feelings. It is in reaction to this disappointment that the text leaps into an analysis of drama. If Berlin cannot be the same city twice, maybe the theater-a practice that relies on an attempt to reprise certain actions-can offer a satisfactory experience of repetition:

There is no young person with any imagination who has not at some time felt himself captured by the magic of the theatre and wished to become part of this mock actuality, in order, as a doppelgänger, to see and hear himself, to disperse himself into a multiplicity of all his possibilities, and yet in such a way that each possibility is a self. (Piety translation, 23)

Kierkegaard describes theatre as a "kunstige Virkelighed". Translated by Piety as "mock actuality", and by the Hongs as "artificial actuality", the original kunstige alludes to art (kunst). Piety misses the artfulness involved, the skillful materialization of what happens on the stage; but the artificiality emphasized by the Hongs underlines falsity over dexterity. Virkelighed implies that something is being realized or presented as factual. Constantius is trying to see if the artful apparitions of theatre can furnish his quest for repetition. Actors repeat for a living, and their art might reveal how 
repetition works. But in spite of all his efforts, Constantius will not recapture his original excitement at the Berlin theatre:

\section{[...] I became bitter, so tired of repetition that I decided to return home. I made no great discovery, yet it was strange, because I had discovered that there was no such thing as repetition. I became aware of this by having it repeated in every possible way. (Piety translation, 38)}

What matters for us here is how Constantius conceptualizes the theatre as a way to experiment with the self. A young person attends the theatre in part to observe himself through others; the stage authorizes a series of alter-identities to play with. To a certain extent, an actor becomes a citation of our own potentiality; like repetition itself, theatre is bi-directional, a bifurcated actuality that is both there and not there-the actor is tangible and virtual at the same time. This is the same effect Kierkegaard is pursuing through his alter-authors: he is dispersing himself into a multiplicity of possibilities that are, simultaneously, many potential selves. Borrowing an idea from Richard Schechner, we can say that the alter-authors were both not Kierkegaard and not-not Kierkegaard: a repetition that cancelled itself out, neither new nor old, and not a mediation between two people, but within one person. Thinking was for Kierkegaard a dramaturgy of positions and recurrences; through his authorships he focused on the conflicted relation between theatricality and actuality. As a result, he gradually proposed a performative dialectic that enabled him to intersect fiction, philosophy, religious meditation and social criticism while rejecting what he believed were the conceptual abstractions of Hegel's Logic.

After Copenhagen I myself went to Berlin, following the fictional steps of Constantius with the very physical steps of my own body. I was repeating a character in a book-an undertaking that Oscar Wilde would have celebrated. But I was also repeating Kierkegaard-he also went to Berlin, and that's why I was there, standing in front of the building where he lived (there is a plaque marking his visit). And Kierkegaard was right (or was it Constantius?): the Gendarmenmarkt close by, with its two domed churches and its theater in the middle is without doubt one of the most enchanting corners of Berlin. It is hard to believe that all this was once bombarded and almost destroyed. It is easy to forget how much of contemporary Berlin is a repetition of its former self, a repetition that recollects the past but also embraces a forward impetus into its next incarnation. But Kierkegaard wrote Gjentagelsen many years before that conflagration that-like all wars, we hope-demands not to be repeated.

Can the dead be taken back? Is recollection enough? For Kierkegaard-Constantius, repetition was both impossible and inevitable. At the street level in the building where he spent some of his Berlin days there is a shop that sells books and prints. I went in and asked if they had any old views that included that building. They didn't, but the employee mentioned that they had some prints from the XIXth century that showed a view of the Gendarmenmarkt as seen from the building. The employee's description was not entirely correct, but I bought one anyhow, and I am looking at it 
right now as I write these lines. How is it that I have ended repeating the gestures of a stranger, a person that for me is mostly a sequence of books and monographs? How is it that I imagined Copenhagen and Berlin through the eyes of Kierkegaard before I ever thought about them on my own behalf? Am I not Kierkegaard and not-not Kierkegaard too, am I playing him, acting him out through my research? Is the task of the historian to produce a well-documented kunstige Virkelighed? I will have to repeat these questions many times.

And so be it.

\title{
Notes
}

\begin{abstract}
${ }^{1}$ Although my main citations come from M.G. Piety's translation (Kierkegaard 2009), I will also utilize another Howard V. and Edna H. Hong's translation (Kierkegaard 2000). The page numbers will refer to either one or the other translation depending on the case.

2 The case-study in question is articulated in Repetition through the story of Constantius' friend, a poet in love. Constantius himself will reveal later that this "friendship" was his own invention. I will not investigate that aspect of the book here.

3 For a more detailed analysis of Kierkegaard's ideas, see Eriksen (2000). This is an excellent study, but I think it overlooks too easily how actors became for Kierkegaard a philosophical example of how repetition is inhabited. This is a topic I will discuss more extensively in a book I am writing at the moment.
\end{abstract}

\section{Works Cited}

Kierkegaard, Søren. 2009. Repetition and Philosophical Crumbs. Translated by M.G. Piety. Oxford: Oxford University Press.

1983. Fear and Trembling. Repetition. Translated by Howard V. and Edna H. Hong. Princeton: Princeton University Press.

Nymann Eriksen, Niels. 2000. Kierkegaard's Category of Repetition. Berlin: Walter de Gruyter.

\section{Biography}

Leo Cabranes-Grant is a Professor at the Departments of Theater and Dance and Spanish and Portuguese (of the last of which he is also Chair) at University of California-Santa Barbara. He teaches Renaissance and Baroque theatre and Latin American and Caribbean performance with an emphasis on intercultural relations. He is also an award winning scholar, poet, and playwright. His book From Scenarios to Networks. Performing the Intercultural in Colonial Mexico was published by Northwestern University Press in 2016. He was also the Editor of Theatre Survey, a journal published by Cambridge University Press for the American Society for Theatre Research (ASTR). At the moment he is working on a book that explores the performative dimensions of Kierkegaard's thought.

(c) 2017 Leo Cabranes-Grant

Except where otherwise noted, this work is licensed under a Creative Commons AttributionNonCommercial-ShareAlike 4.0 International License. 